\title{
Iron-Induced Thrombocytopenia: A Mini-Review of the Literature and Suggested Mechanisms
}

\author{
Mona Babikir ${ }^{1}$, Rita Ahmad $^{2}$, Ashraf Soliman $^{3}$, Mustafa Al-Tikrity ${ }^{1}$, Mohamed A. Yassin ${ }^{4}$ \\ 1. Internal Medicine, Hamad Medical Corporation, Doha, QAT 2. Family Medicine, Hamad Medical Corporation, Doha, \\ QAT 3. Pediatric Endocrinology, Hamad Medical Corporation, Doha, QAT 4. Hematology and Oncology, Hamad General \\ Hospital, Doha, QAT
}

Corresponding author: Mona Babikir, mbabikir@hamad.qa

\begin{abstract}
Anemia constitutes a major global health burden, and iron deficiency is the most common cause of it. Iron deficiency and replacement affect not only hemoglobin $(\mathrm{Hb})$ levels but also other hematological parameters such as platelet count. In this mini-review, we explore thrombocytopenia as a side effect of iron replacement therapy. We searched for relevant articles published in English, and all case reports/series of iron-induced thrombocytopenia were collected and analyzed. A total of 11 case reports and one case series were found relating to very low $\mathrm{Hb}$ at a baseline level of $5.25+/-2.2 \mathrm{~g} / \mathrm{dl}$ and variable platelet count at baseline that dropped in $9+/-3$ days to an average of $121+/-112 \times 10^{9} / \mathrm{L}$, which in most of the cases was self-corrected. The parenteral route was more commonly reported to be associated with thrombocytopenia, and discontinuation of therapy was needed in two patients.
\end{abstract}

The mechanisms, prevalence, and clinical significance of thrombocytopenia associated with iron replacement are unknown; several effects of iron on the primary hematopoietic cells and stromal cell lines have been proposed, such as influence on common progenitors, effects on cytokines, and thrombopoietic effect of erythropoietin, which is directly affected by iron levels. Iron replacement can lead to significant thrombocytopenia. Further research is needed to describe the exact incidence, mechanism, and clinical significance of thrombocytopenia associated with iron supplementation.

Received 06/17/2020 Review began 06/21/2020 Review ended 08/05/2020 Published 09/02/2020

(c) Copyright 2020 Babikir et al. This is an open access article distributed under the terms of the Creative Commons Attribution License CC-BY 4.0., which permits unrestricted use, distribution, and reproduction in any medium, provided the original author and source are credited.
Categories: Internal Medicine, Hematology

Keywords: deficiency, iron, replacement, supplement, anemia, thrombocytopenia, platelet

\section{Introduction And Background}

Anemia is defined by the World Health Organization as "a condition in which the number of red blood cells (and consequently their oxygen-carrying capacity) is insufficient to meet the body's physiologic needs" [1]. The worldwide prevalence of anemia at $\sim 24.8 \%$ [2] and its association with increased morbidity and mortality and decreased work productivity have made it an important public health burden [1,2]. Iron deficiency is the most common cause of anemia worldwide. Approximately $5 \%$ and $2 \%$ of American women and men, respectively, suffer from iron deficiency anemia (IDA) [3]. It occurs due to the unmet demand for iron to form normal red blood cells.

IDA is generally caused by inadequate intake of iron, chronic blood loss, or a combination of both [3-5]. A less common cause is malabsorption of iron secondary to gastric and/or duodenal resection or inflammatory conditions like infectious or atrophic gastritis, or tropical sprue. A rare cause includes a genetic mutation in TMPRSS6 leading to iron-refractory IDA [6]. Iron deficiency is often associated with thrombocytosis rather than thrombocytopenia; however, both have been described in the literature for more than 50 years [7]. On the other hand, iron replacement has a similar range of effects on thrombopoiesis [8].

In this article, we review the relevant literature published in English to shed light on the link between iron replacement and thrombocytopenia in patients with IDA.

\section{Review}

\section{Methods}

We searched the databases PubMed and Scopus for all relevant articles published in the literature in English using the following Medical Subject Headings (MeSH) terms: [deficiency, Iron] [replacement] [supplement] [anemia] [thrombocytopenia] [platelet]. Data were then collected, recorded, and analyzed.

\section{Results}

A total of 11 individual case reports and one case series (containing 9 patients) were found, which are summarized in Tables 1-4 [9-19]. The age of the patients in the study ranged between 15 and 42 years, and a female predominance was observed (a female-to-male ratio of approximately $3: 1$ ) (Table 1). At baseline, 


\section{Cureus}

the hemoglobin $(\mathrm{Hb})$ concentration was $5.25+/-2.2 \mathrm{~g} / \mathrm{dl}$, serum iron concentration was $20+/-12.8 \mathrm{ug} / \mathrm{dl}$, and serum ferritin level was $9+/-11.8 \mathrm{ng} / \mathrm{dl}$, denoting a severe form of IDA. After iron replacement, $\mathrm{Hb}$ concentration increased to $8.03+/-1.47$ and serum iron concentration increased to $78+/-22.5 \mathrm{ug} / \mathrm{dl}$ (Table 2). Before iron therapy, the platelet count was $469+/-404 \times 10^{9} / \mathrm{L}$. The nadir platelet count occurred after 9 $+/-3$ days to a mean count of $121+/-112 \times 10^{9} / \mathrm{L}$ (Table 3). The intravenous route was associated with a higher incidence of iron-associated thrombocytopenia than oral and intramuscular routes. Two patients needed platelet transfusions. Thrombocytopenia led to discontinuation of iron replacement in two patients. Both were receiving iron sucrose (Table 4). In the last follow-up of those patients, $\mathrm{Hb}$ concentration was found to be increased to $11.5+/-2.3 \mathrm{~g} / \mathrm{dl}$, and platelet count had increased to $322+/-233 \times 10^{9} / \mathrm{L}$.

\begin{tabular}{|c|c|c|c|c|c|}
\hline No & Authors & Year of publication & Patient gender & Patient age (years) & Patient ethnicity \\
\hline 1 & Giordano et al. [9] & 2019 & Male & 16 & African \\
\hline 2 & Bayhan et al. [10] & 2016 & Female & 15 & NA \\
\hline 3 & Kahraman et al. [11] & 2016 & Male & 17 & NA \\
\hline 4 & Cunha et al. [12] & 2015 & Female & 16 & NA \\
\hline 5 & Lindgren et al. [13] & 2009 & Male & NA & NA \\
\hline 6 & Ganti et al. [14] & 2007 & Female & 39 & African American \\
\hline 7 & Taskapan et al. [15] & 2003 & Female & 37 & NA \\
\hline 8 & Go et al. [16] & 2000 & Female & 30 & $\mathrm{NA}$ \\
\hline 9 & Soff and Levin (case 1) [17] & 1988 & Female & 17 & NA \\
\hline 10 & Soff and Levin (case 2) [17] & 1988 & Female & 17 & NA \\
\hline 11 & Knizley et al. [18] & 1972 & Male & 42 & Black \\
\hline 12 & Lioger et al. (series) [19] & 2016 & 1 male, 8 females & NA & NA \\
\hline
\end{tabular}

TABLE 1: Cases publication year, and age, gender, and ethnicity of patients

NA: not available 


\section{Cureus}

\begin{tabular}{|c|c|c|c|c|c|c|c|c|c|c|c|}
\hline No & Authors & $\begin{array}{l}\mathrm{Hb} \text { at } \\
\text { baseline }\end{array}$ & MCV & $\begin{array}{l}\text { Hb during } \\
\text { replacement }\end{array}$ & $\begin{array}{l}\text { Hb after } \\
\text { replacement }\end{array}$ & $\begin{array}{l}\text { Iron at } \\
\text { baseline }\end{array}$ & $\begin{array}{l}\text { Iron after } \\
\text { replacement }\end{array}$ & $\begin{array}{l}\text { Fe sat } \\
\text { at } \\
\text { baseline }\end{array}$ & $\begin{array}{l}\text { Fe sat after } \\
\text { replacement }\end{array}$ & $\begin{array}{l}\text { Ferritin } \\
\text { at } \\
\text { baseline }\end{array}$ & $\begin{array}{l}\text { Ferritin after } \\
\text { replacement }\end{array}$ \\
\hline 1 & $\begin{array}{l}\text { Giordano } \\
\text { et al. [9] }\end{array}$ & $5.2 \mathrm{~g} / \mathrm{dL}$ & $54.5 \mathrm{fL}$ & 8.4 g/dL & $13.3 \mathrm{~g} / \mathrm{dL}$ & NA & NA & NA & NA & $\begin{array}{l}3.1 \\
\mathrm{ng} / \mathrm{mL}\end{array}$ & NA \\
\hline 2 & $\begin{array}{l}\text { Bayhan et } \\
\text { al. [10] }\end{array}$ & $4.7 \mathrm{~g} / \mathrm{dL}$ & $64.2 \mathrm{fL}$ & $8.2 \mathrm{~g} / \mathrm{dL}$ & $9.6 \mathrm{~g} / \mathrm{dL}$ & NA & NA & $9.50 \%$ & $\mathrm{Na}$ & $\begin{array}{l}2.4 \\
\mathrm{ng} / \mathrm{mL}\end{array}$ & NA \\
\hline 3 & $\begin{array}{l}\text { Kahraman } \\
\text { et al. [11] }\end{array}$ & $7.6 \mathrm{~g} / \mathrm{dL}$ & $66 \mathrm{fL}$ & NA & NA & $\begin{array}{l}27 \\
\mu \mathrm{g} / \mathrm{dL}\end{array}$ & NA & NA & NA & $3 \mathrm{ng} / \mathrm{mL}$ & NA \\
\hline 4 & $\begin{array}{l}\text { Cunha et } \\
\text { al. [12] }\end{array}$ & $5.8 \mathrm{~g} / \mathrm{dL}$ & $63 \mathrm{fL}$ & $8.1 \mathrm{~g} / \mathrm{dl}$ & $8.8 \mathrm{~g} / \mathrm{dl}$ & NA & $78 \mathrm{mcg} / \mathrm{dl}$ & NA & NA & NA & NA \\
\hline 5 & $\begin{array}{l}\text { Lindgren } \\
\text { et al. [13] }\end{array}$ & NA & NA & NA & NA & NA & NA & NA & NA & NA & NA \\
\hline 6 & $\begin{array}{l}\text { Ganti et } \\
\text { al. [14] }\end{array}$ & $3.1 \mathrm{~g} / \mathrm{dL}$ & $58.6 \mathrm{fL}$ & $5.2 \mathrm{~g} / \mathrm{dL}$ & $14.0 \mathrm{~g} / \mathrm{dL}$ & $\begin{array}{l}17 \\
\mu \mathrm{g} / \mathrm{dL}\end{array}$ & NA & $4 \%$ & NA & $\begin{array}{l}<2 \\
\mathrm{ng} / \mathrm{dL}\end{array}$ & $121 \mathrm{ng} / \mathrm{mL}$ \\
\hline 7 & $\begin{array}{l}\text { Taskapan } \\
\text { et al. [15] }\end{array}$ & $10.1 \mathrm{~g} / \mathrm{dL}$ & $88.2 \mathrm{fL}$ & $8.9 \mathrm{~g} / \mathrm{dL}$ & $9.9 \mathrm{~g} / \mathrm{dL}$ & $\begin{array}{l}19 \\
\mu \mathrm{g} / \mathrm{dL}\end{array}$ & NA & $7 \%$ & NA & $\begin{array}{l}35.5 \\
\mu \mathrm{g} / \mathrm{L}\end{array}$ & NA \\
\hline 8 & $\begin{array}{l}\text { Go et } \\
\text { al. [16] }\end{array}$ & $3.1 \mathrm{~g} / \mathrm{dL}$ & $77 \mathrm{fL}$ & NA & NA & $5 \mu / d L$ & NA & $1 \%$ & NA & $8 \mathrm{mg} / \mathrm{L}$ & NA \\
\hline 9 & $\begin{array}{l}\text { Soff and } \\
\text { Levin } \\
\text { (case 1) } \\
{[17]}\end{array}$ & $3.2 \mathrm{~g} / \mathrm{dL}$ & & & & $\begin{array}{l}22 \\
\mu \mathrm{g} / \mathrm{dL}\end{array}$ & NA & NA & NA & $\begin{array}{l}<10 \\
\mathrm{ng} / \mathrm{ml}\end{array}$ & NA \\
\hline 10 & $\begin{array}{l}\text { Soff and } \\
\text { Levin } \\
\text { (case 1) } \\
{[17]}\end{array}$ & $3.2 \mathrm{~g} / \mathrm{dL}$ & Low & NA & NA & $7 \mu / \mathrm{dL}$ & NA & NA & NA & NA & NA \\
\hline 11 & $\begin{array}{l}\text { Knizley et } \\
\text { al. [18] }\end{array}$ & $6.1 \mathrm{~g} / \mathrm{dL}$ & & $9.4 \mathrm{~g} / \mathrm{dL}$ & $13.6 \mathrm{~g} / \mathrm{dL}$ & $43 \mathrm{mg} / \mathrm{dl}$ & NA & $8 \%$ & NA & NA & NA \\
\hline 12 & $\begin{array}{l}\text { Lloger et } \\
\text { al. (series) } \\
\text { [19] }\end{array}$ & $\begin{array}{c}5.7 \pm \\
2.3 \mathrm{~g} / \mathrm{dL}\end{array}$ & $63 \mathrm{fL}$ & NA & NA & NA & NA & NA & NA & NA & \\
\hline
\end{tabular}

TABLE 2: Hemoglobin and iron profile at baseline and during and after iron therapy

$\mathrm{Hb}$ : hemoglobin; MCV: mean corpuscular volume; Fe sat: iron saturation; NA: not available 


\section{Cureus}

\begin{tabular}{|c|c|c|c|c|c|}
\hline No & Authors & Platelet at baseline & Lowest platelet count & Days to nadir & Last platelet count \\
\hline 1 & Giordano et al. [9] & $40 \mathrm{k} / \mu \mathrm{L}$ & $28 \mathrm{k} / \mu \mathrm{L}$ & 5 & $169 \mathrm{k} / \mu \mathrm{L}$ \\
\hline 2 & Bayhan et al. [10] & $820 \times 10^{9} / L$ & $48 \times 10^{9} / L$ & 12 & $363 \times 10^{9} / \mathrm{L}$ \\
\hline 3 & Kahraman et al. [11] & $340 \times 10^{3} / \mathrm{mcL}$ & $68 \times 10^{3} / \mathrm{mcL}$ & 7 & $159 \times 10^{3} / \mathrm{mcL}$ \\
\hline 4 & Cunha et al. [12] & $424 \times 10^{9} / \mathrm{L}$ & $45 \times 10^{9} / \mathrm{L}$ & 8 & $666 \times 10^{9} / L$ \\
\hline 5 & Lindgren et al. [13] & NA & $\mathrm{NA}$ & NA & NA \\
\hline 6 & Ganti et al. [14] & $127 \times 10^{3} / \mathrm{mcL}$ & $39 \times 10^{3} / \mathrm{mcL}$ & 2 & $181 \times 10^{3} / \mathrm{mcL}$ \\
\hline 7 & Taskapan et al. [15] & $102,000 / L$ & $2,000 / L$ & 8 & $87,000 / \mathrm{L}$ \\
\hline 8 & Go et al. [16] & $426 \times 10^{9} / L$ & $20 \times 10^{9} / L$ & 8 & NA \\
\hline 9 & Soff and Levin (case 1) [17] & $168,000 / \mathrm{mm}^{3}$ & $21,000 / \mathrm{mm}^{3}$ & 6 & $683,000 / \mathrm{mm}^{3}$ \\
\hline 10 & Soff and Levin (case 2) [17] & $717,000 / \mathrm{mm}^{3}$ & $105,000 / \mathrm{mm}^{3}$ & 10 & NA \\
\hline 11 & Knizley et al. [18] & $1,465,000 / \mathrm{mm}^{3}$ & $37,000 / \mathrm{mm}^{3}$ & 13 & $265,000 / \mathrm{mm}^{3}$ \\
\hline 12 & Lioger et al. (series) [19] & $172 \pm 133 \times 10^{9} / \mathrm{L}$ (range: $102-434$ ) & $85 \%$ from baseline & & NA \\
\hline
\end{tabular}

\section{TABLE 3: Platelet count before, during, and after replacement}

NA: not available

\begin{tabular}{|c|c|c|c|c|c|}
\hline No & Authors & Route of iron replacement & Type of iron replacement & Dose & Discontinuation \\
\hline 1 & Giordano et al. [9] & Oral & Ferrous sulfate & NA & No \\
\hline 2 & Bayhan et al. [10] & Oral & Ferrous glycıne sultate & 4 mg/kg & No \\
\hline 3 & Kahraman et al. [11] & IV & Iron sucrose & 100 mg/day & No \\
\hline 4 & Cunha et al. [12] & IV & Iron sucrose & $100 \mathrm{mg}$ & Yes \\
\hline 5 & Lindgren et al. [13] & NA & NA & NA & NA \\
\hline 6 & Ganti et al. [14] & IV & Iron sucrose & 100 mg 2xwk & No \\
\hline 7 & Taskapan et al. [15] & IV & Iron sucrose & 200 mg daily & No \\
\hline 8 & Go et al. [16] & IM & Iron dextran & 100 mg/day & Yes (changed to oral) \\
\hline 9 & Soff and Levin (case 1) [17] & Oral & Ferrous sulfate & $300 \mathrm{mg}$ TID & NA \\
\hline 10 & Soff and Levin (case 2) [17] & Oral & Ferrous gluconate & & NA \\
\hline 11 & Knizley et al. [18] & Oral & Ferrous sulfate & 235 mg TID & No \\
\hline 12 & Lioger et al. (series) [19] & IV: 8, IM: 1 & Iron sucrose/terric carboxymaltose & NA & NA \\
\hline
\end{tabular}

TABLE 4: Iron replacement route, preparation, and dose, and whether discontinuation/transfusion was required

IV: intravenous; IM: intramuscular; NA: not available

\section{Discussion}

Thrombocytopenia may occur in patients with severe IDA who receive iron therapy; however, it is very uncommon [3]. Its pathogenesis remains undetermined but is thought to be related to the alteration in the 
Iron has a synthetic and regulatory role in platelet production, and animal models have suggested a common progenitor cell for erythroid and megakaryocytic cell lineages [21]. The reviewed cases who developed thrombocytopenia after iron replacement, especially parenteral iron, had a significant reduction in platelet count that was self-corrected in most of the cases. The mechanisms, prevalence, and clinical significance of this thrombocytopenia are unknown [15-18,22]. Iron has a synthetic and regulatory role in platelet production. Iron can induce cell death by generating free radicals as it interconverts between ferrous $(\mathrm{Fe} 2+)$ and ferric (Fe3+) forms. A randomized, placebo-controlled, double-blind, parallel-group study was performed on 38 peritoneal dialysis patients before and after a single intravenous infusion of $300 \mathrm{mg}$ iron sucrose. Iron infusion increased in total $(\Delta 601 \mu \mathrm{g} / 100 \mathrm{~mL}, \mathrm{CI} 507,696)$ and non-transferrin-bound iron $(\Delta$ $237.2 \mu \mathrm{mol} / \mathrm{L}$, CI 173.6, 300.8) increased approximately by 10 -fold, as well as redox-active iron by nearly five-fold $(\Delta 0.76 \mu \mathrm{mol} / \mathrm{L}, \mathrm{CI} 0.54,0.98)[23]$.

Animal models have suggested a common progenitor cell for erythroid and megakaryocytic cell lineages [21]. An in vitro study examined the effects of iron load (that may simulate the process of iron infusion in patients with IDA) on the function of primary hematopoietic cells and stromal cell lines and found that iron overload impairs normal hematopoietic cells and modifies the function of stromal cells, indicating that iron overload impairs the whole hematopoietic system. The authors suggested that the deleterious effects of iron were mediated through its impact on hematopoietic stem/progenitor cells as well as in differentiated hematopoietic via reactive oxygen species (ROS) accumulation [24]. In addition, an in-vitro study showed that ferrous ammonium sulfate (FeAS) induced growth arrest and apoptosis in immature hematopoietic cells and led to insulin-like growth factor binding protein 2 (IGFBP2) and insulin-like growth factor 1 (IGF-1) down-regulation. Both have been found to stimulate the survival, proliferation, and cycling of hematopoietic stem cells (HSCs) [25].

Although thrombopoietin is the primary growth factor and regulator of megakaryopoiesis, several other cytokines such as interleukin (IL)-1, IL-3, IL-6, IL-11, and tumor necrosis factor are also involved in this process [26-28]. Erythropoietin shares some structural features with thrombopoietin and may exhibit a synergistic effect on platelet production. The levels of endogenous erythropoietin significantly decrease during the correction of iron deficiency. This reduction in endogenous erythropoietin might decrease the productivity of megakaryocytes and lead to transient thrombocytopenia [29,30].

In this study, we observed that young females are more likely to be affected by IDA. Further research is needed to explore whether this is because IDA per se is more common in this population or if there are other explanations related to female sex hormone or genetic profile. Another observation was that platelet nadir occurred within 13 days of iron replacement initiation; however, the number of cases was too small to recommend following platelet count in asymptomatic patients within this timeframe.

\section{Conclusions}

Significant thrombocytopenia occasionally occurs in patients receiving iron therapy for IDA. This condition is transient and self-limited in most of these cases. Various mechanisms can contribute to this thrombocytopenia. Dedicated observational and experimental studies are needed to describe the correlation between iron profile, hemoglobin level, genetic factors, cytokines, growth factors and thrombopoiesis; these studies should look for predictors that could determine which individuals will get thrombocytopenia on receiving iron supplements.

\section{Additional Information \\ Disclosures}

Conflicts of interest: In compliance with the ICMJE uniform disclosure form, all authors declare the following: Payment/services info: All authors have declared that no financial support was received from any organization for the submitted work. Financial relationships: All authors have declared that they have no financial relationships at present or within the previous three years with any organizations that might have an interest in the submitted work. Other relationships: All authors have declared that there are no other relationships or activities that could appear to have influenced the submitted work.

\section{Acknowledgements}

We would like express our gratitude to everyone at the Internal Medicine Residency Program, Hamad Medical Corporation, Doha, Qatar

\section{References}

1. World Health Organization: serum transferrin receptor levels for the assessment of iron status and iron deficiency in populations. (2014). Accessed: August 15, 2020: https://apps.who.int/iris/bitstream/handle/10665/133707/WHO_NMH_NHD_EPG_14.6_eng.pdf.

2. Gebreweld A, Ali N, Ali R, Fisha T: Prevalence of anemia and its associated factors among children under 
five years of age attending at Guguftu health center, South Wollo, Northeast Ethiopia. PLoS One. 2019, 14:e0218961. 10.1371/journal.pone.0218961

3. Johnson-Wimbley TD, Graham DY: Diagnosis and management of iron deficiency anemia in the 21st century. Therap Adv Gastroenterol. 2011, 4:177-184. 10.1177/1756283X11398736

4. Li Q, Liang F, Liang W, Shi W, Han Y: Prevalence of anemia and its associated risk factors among 6-monthsold infants in Beijing. Front Pediatr. 2019, 7:286. 10.3389/fped.2019.00286

5. World Health Organization: haemoglobin concentrations for the diagnosis of anaemia and assessment of severity. (2011). Accessed: August 15, 2020: https://www.who.int/vmnis/indicators/haemoglobin/en/.

6. Saboor M, Zehra A, Qamar K, Moinuddin: Disorders associated with malabsorption of iron: a critical review . Pak J Med Sci. 2015, 31:1549-1553. 10.12669/pjms.316.8125

7. Morris VK, Spraker HL, Howard SC, Ware RE, Reiss UM: Severe thrombocytopenia with iron deficiency anemia. Pediatr Hematol Oncol. 2010, 27:413-419. 10.3109/08880011003739455

8. Evstatiev R, Bukaty A, Jimenez K, et al.: Iron deficiency alters megakaryopoiesis and platelet phenotype independent of thrombopoietin. Am J Hematol. 2014, 89:524-529. 10.1002/ajh.23682

9. Giordano L, Llanos-Chea A, Monde A, Mulinge I, Dighe D: Recurrent severe iron deficiency anemia and thrombocytopenia in an adolescent male. J Pediatr Hematol Oncol. 2019, 41:e116-e118. 10.1097/MPH.0000000000001162

10. Bayhan T, Ünal Ş, Gümrük F, Çetin M: A rare complication of a common problem: thrombocytopenia subsequent to iron replacement therapy in an adolescent girl with severe iron deficiency anaemia. Hong Kong J Paediatr. 2016, 21:113-115.

11. Kahraman C, Üçgün S, Kahraman NK: Intravenous iron infusion induced severe temporary thrombocytopenia case in iron deficiency anemia: a review. Ann Med Med Educ. 2016, 3:7-10. 10.12973/amme.2016.00148a

12. Cunha V, Ferreira M, Barosa R, Fonseca AG, Delerue F, Carvalho C: Iron-induced thrombocytopenia in severe iron-deficiency anemia. Expert Rev Hematol. 2015, 8:247-251. 10.1586/17474086.2015.1010504

13. Lindgren $\mathrm{S}$, Wikman $\mathrm{O}$, Befrits $\mathrm{R}$, et al.: Intravenous iron sucrose is superior to oral iron sulphate for correcting anaemia and restoring iron stores in IBD patients: a randomized, controlled, evaluator-blind, multicentre study. Scand J Gastroenterol. 2009, 44:838-845. 10.1080/00365520902839667

14. Ganti AK, Shonka NA, Haire WD: Pancytopenia due to iron deficiency worsened by iron infusion: a case report. J Med Case Rep. 2007, 1:175. 10.1186/1752-1947-1-175

15. Taskapan H, Bahceci F, Taskapan C, Sahin I, Kaya E, Aydogdu I: Transient severe thrombocytopenia in a patient on CAPD after intravenous iron administration. Perit Dial Int. 2003, 23:408-409.

16. Go RS, Porrata LF, Call TG: Thrombocytopenia after iron dextran administration in a patient with severe iron deficiency anemia. Ann Intern Med. 2000, 132:925. 10.7326/0003-4819-132-11-200006060-00025

17. Soff GA, Levin J: Thrombocytopenia associated with repletion of iron in iron-deficiency anemia . Am J Med Sci. 1988, 295:35-39. 10.1097/00000441-198801000-00008

18. Knizley H Jr, Noyes WD: Iron deficiency anemia, papilledema, thrombocytosis, and transient hemiparesis . Arch Intern Med. 1972, 129:483-486. 10.1001/archinte.1972.00320030103013

19. Lioger B, Beurier P, Biogeau J, Jonville-Bera AP, Ollier S, Ferreira-Maldent N, Maillot F: Thrombocytopenia after iron infusion: a case series of four patients and review of literature. Haematologica. 2016, 101:850851.

20. Jhamb R, Kumar A: Iron deficiency anemia presenting as pancytopenia in an adolescent girl . Int J Adolesc Med Health. 2011, 23:73-74. 10.1515/ijamh.2011.012

21. Batra S, Gupta A, Peddint R: An unusual case of thrombocytopenia. Clin Pediatr (Phila). 2011, 50:464-466. 10.1177/0009922809354333

22. Özdemir N, Celkan T, Kebudi R, Bor M, Yildiz I: Cytopenia associated with iron deficiency anemia and iron therapy: a report of two cases. Turk J Haematol. 2011, 28:243-244. 10.5152/tjh.2011.65

23. Schaller G, Scheiber-Mojdehkar B, Wolzt M, et al.: Intravenous iron increases labile serum iron but does not impair forearm blood flow reactivity in dialysis patients. Kidney Int. 2005, 68:2814-2822. 10.1111/j.15231755.2005.00754.x

24. Tanaka H, Espinoza JL, Fujiwara R, et al.: Excessive reactive iron impairs hematopoiesis by affecting both immature hematopoietic cells and stromal cells. Cells. 2019, 8:226. 10.3390/cells8030226

25. Huynh H, Zheng J, Umikawa M, et al.: IGF binding protein 2 supports the survival and cycling of hematopoietic stem cells. Blood. 2011, 118:3236-3243. 10.1182/blood-2011-01-331876

26. Kaushansky K: Thrombopoietin: the primary regulator of platelet production . Blood. 1995, 86:419-431.

27. Wendling F, Han ZC: Positive and negative regulation of megakaryocytopoiesis. Baillieres Clin Haematol. 1997, 10:29-45. 10.1016/s0950-3536(97)80049-2

28. Broudy VC, Lin NL, Kaushansky K: Thrombopoietin (c-mpl ligand) acts synergistically with erythropoietin, stem cell factor, and interleukin-11 to enhance murine megakaryocyte colony growth and increases megakaryocyte ploidy in vitro. Blood. 1995, 85:1719-1726.

29. Metcalf D, Di Rago L, Mifsud S: Synergistic and inhibitory interactions in the in vitro control of murine megakaryocyte colony formation. Stem Cells. 2002, 20:552-560. 10.1002/stem.200552

30. Akan H, Güven N, Aydogdu I, Arat M, Beksaç M, Dalva K: Thrombopoietic cytokines in patients with iron deficiency anemia with or without thrombocytosis. Acta Haematol. 2000, 103:152-156. 10.1159/000041038 